\title{
Pent-up demand's realization in the hospitality sector in the context of COVID-19
}

\author{
Valeriia Kostynets \\ Department of Economics and Services, \\ Faculty of Economics and Business, \\ Kyiv National University of Technology and Design, Ukraine \\ valeriya1989@i.ua \\ ORCID 0000-0002-4222-7620
}

\section{Iuliia Kostynets}

Acting Head of Department of Marketing and Communicative Design, Kyiv National University of Technology and Design, Ukraine yulia.kostinets@gmail.com ORCID 0000-0001-6427-675X

\section{Oleksandra Olshanska}

Dean of Faculty of Economics and Business, Kyiv National University of Technology and Design, Ukraine deanfebknutd@gmail.com

ORCID 0000-0003-1535-7742

Abstract. The article is dedicated to modelling the realization of pent-up demand based on the relationship between the incoming traffic of online booking platforms in the hospitality sector and the volume of tourist arrivals in the context of COVID-19 spread. The authors conducted a study on the current trends in the hospitality sector in the aspect of the industry's functioning under COVID19. The authors identified the development prospects for the hospitality sector as a component of the tourist services market in the context of easing restrictions in the countries of tourist arrivals. The article established the specifics of the pentup demand realization based on the results of the international flights renewal and the functioning of the hospitality industry under COVID-19. The authors analyzed the consumer requests on popular online booking services, Airbnb and Booking.com, during the period of partial easing of the restrictions on the movement of tourists, starting from July 2020. Based on the conducted regression analysis, the density of communication between the incoming traffic of the online booking platforms in the hospitality sector and the volume of tourist arrivals in the context of the COVID-19 spread was established. Based on the regression modelling, realization of demand in the hospitality sector was forecasted. 
Keywords: pent-up demand, hospitality industry, travel services market, COVID-19

JEL Classification: M21, R22, L83, G01, O50

\section{INTRODUCTION}

In the first ten months of 2020 , there was a $72 \%$ drop in the international tourist arrivals, due to the global travel restrictions, falling incomes of consumers and the global fight to contain the COVID-19 virus. For sure, 2020 was the worst year for tourism in the entire history of its development.

According to the latest data by the World Tourism Organization (UNWTO), for the period from January to October 2020, tourist destinations received 900 million fewer international tourists as compared to the same period back in 2019. This means a shortfall of USD 935 billion in exports from international tourism, which exceeds the losses that happened in 2009 due to the global economic crisis by more than 10 times.

Despite some improvement recorded during the summer peak months for international tourism - July and August - the results were slightly worse in September and October, which was due to an increase in COVID-19 cases in the world, the re-introduction of travel restrictions, primarily in Europe, and the constant closure of borders in many directions, in particular in Asia and the Pacific. At the same time, Australia has already announced that there are no plans to open borders to foreign tourists during 2021 (UNWTO, 2020).

The estimated decrease in the number of foreign citizens who arrived in the first twelve months of 2020 is equivalent to a loss of about 1 bln tourists and about USD 1.1 trillion in revenues from international tourism. Such a decline in international tourism could lead to economic losses in the global GDP of more than USD 2 trillion, thus exceeding 2\% of the global GDP in 2019 (UNWTO, 2020).

At the same time, the data obtained from the recent UNWTO studies show that the share of closed tourist destinations decreased from 82\% at the end of April 2020 to 18\% at the beginning of November last year.

Structurally, this study consists of the following sections: 1) Introduction in which the relevance of the studied issue is explained; 2) review of the literature on the impact of COVID-19 on the hospitality sector; 3) defining of the purpose, objectives and methodology of the study; 4) highlighting the main theoretical results of the study and demonstration of the empirical implementation of the research results; 5) conclusions and prospects for further research.

\section{LITERATURE REVIEW}

COVID-19 and its consequences have become the subject of research for representatives of world scientific and socio-political thought. In scientific works that dedicated to the study of the hospitality sector, there's insufficient volume of scientific developments that analyze the impact of pandemics on the tourism market and the hotel business, so we focus on the key aspects of this issue.

Thus, in his research, F. Burkle (2006) noted that the interaction between pandemic and travel is key to understanding health safety and global changes. Researcher Yu. Kabelkaite-Weitken (2020) draws attention to the fact that the coronavirus pandemic has globally affected tourism demand and, as a result, the hospitality industry - one of the largest employers in the world. Losses were incurred by all classes of hotels in all countries, however, separately, she notes that small accommodation facilities and non-workrelated hotel facilities operating on leased space were most at risk (Kostynets et al., 2020). 
It should be noted that S. Butorov (2020) notes that the scale of the epidemic, it's rapid spread, the number of victims and infected people, and its ability to cause irreparable damage to the global economy indicate that humanity has entered an era of global catastrophes, new threats and challenges. In turn, the concept of "challenge" was introduced into scientific use by the English historian A. Toynbee (Toynbee, 2019). Studying the history of human civilizations, he came to the conclusion that the survival or death of each of them was the result of how they reacted to a new problem - a challenge. The development of civilization is determined by whether the creative minority is able to find answers to the challenges of the natural world and the human environment. A. Toynbee identifies the following types of challenges: the challenge of a harsh climate; the challenge of new lands; the challenge of sudden blows from neighbouring societies; the challenge of constant external pressure and the challenge of restriction, when society, having lost something vital, directs its energy to develop properties that compensate for the loss. During the development of "Challenge and Response" theory by A. Toynbee in the middle of previous century humanity was not on the verge of such a catastrophe, that happened in 2020.

P. Ozili and T. Arun (Ozili, \& Arun, 2020) in their research provided a list of COVID-19 stats, including confirmed cases, deaths, re-infections, in several countries and continents, and noted the global impact of COVID-19 on the hotel and restaurant business. The researchers looked at a number of political actions and measures in different countries of the world to battle the spread of COVID-19 and, accordingly, classified them into four groups: 1) measures to control human movement; 2) health measures; 3) fiscal measures; 4) monetary measures. "Measures to control" category contains restrictions on foreign travel, domestic travel restrictions, state of emergency declarations, restrictions on mass gatherings, school closures, and restrictions of stores and restaurants operation.

N. Bakar and S. Rosby (2020) used the supply and demand curve in their research to analyze the economic impact of COVID-19 on the hospitality industry. To develop the supply and demand curve, the demand function was created with factors that determine the price of selected products, customer tastes and preferences, consumer expectations, average income of certain countries, and the number of customers. The findings of their study were well expected and point to the devastating impact of the effects of COVID19 measures on the hospitality sector.

R. Centeno and J. Marquez (Centeno, \& Marquez, 2020) in their research developed seasonal autoregressive integrated models of moving average for the Tourism and hospitality industry in the Philippines, predicting a total revenue loss of about 1170.5 bln Philippine pesos, equivalent to USD 3.37 bln from the effects of COVID-19 until the end of July 2020. In order to ease the impact of the pandemic on the hospitality industry, the authors suggested to divide the country into two regions according to the level of infection risk (high and low) and allowing domestic travel to low-risk regions.

F. Gunay, E. Bayraktaroglu and K. Ozkul (2020) applied scenario analysis methodology to calculate the impact of COVID-19 on the Turkish tourism and hospitality industry. Their model predicts a total loss of revenue in the best and worst - case scenarios of USD 1.5 bln \& USD $15.2 \mathrm{bln}$, respectively for 2020. The worst-case scenario, which fortunately did not materialize, involved closing the borders for 4 months without any economic recovery.

K. Mekhta's research focused on the impact of COVID-19 on India's economy, with a profit loss of about USD 28 bln in 2020, as well as 70\% job losses for tourism and hospitality workers and massive bankruptcies on the market (2020). Trend analysis has also been used to examine the impact of COVID-19 on the global tourism and hotel services market and global GDP as a whole. According to I. Priyadarshini, global revenues of the hospitality industry will fall by $17 \%$ compared to 2019 . The study also predicted that North America, Europe and Asia will suffer the biggest losses in global revenue. The decline in hospitality revenue will mainly be observed in the United States, Germany, Italy and China by 10\%, 10\%, 24\% and $40 \%$, respectively (Priyadarshini, 2020). 
T. Cajner, L. D. Crane, R. A. Decker (Cajner, Crane, \& Decker, 2020) and others analyzed the impact of the COVID-19 pandemic on the US labor market. According to the study, between March 13 and March 28, 2020, about 13 million paid jobs were lost. At that, authors note that only 9 million paid jobs were lost during the Great Depression of the 1930s, accounting for less than $70 \%$ of the pandemic job loss. This study also highlighted that it was the hospitality industry that was most affected by this crisis.

Based on the analysis of scientific sources, it should be noted that despite the presence of a certain number of scientific developments related to the impact of COVID-19 on the hospitality sector, as of now, the topic of realization of pent-up demand for hospitality services, considering functioning of the tourist services market in the context of epidemiological threats, political collapses and financial crises remains undisclosed.

\section{METHODOLOGY}

The aim of the study is to model the relationship between the incoming traffic of online booking platforms in the hospitality sector and the volume of tourist arrivals in the context of the spread of COVID19. Establishing of this relationship and checking of the correlation between these indicators will allow us to assess the statistical significance of regression and correlation parameters and predict the recovery and realization of pent-up demand for services in the hospitality sector.

In accordance with the aim of the study, the main objectives of the study were to analyze the current state and prospects of the development of the hospitality sector as a component of the tourist services market in the context of easing restrictions in the countries of tourist arrivals; to establish opportunities and determine the features of realization of pent-up demand based on the results of the resumption of international flights and the functioning of the hospitality industry in the conditions of COVID-19.

Methods of economic dynamics analysis, structural and functional analysis, scientific abstraction, as well as the graphical method and econometric methods of nonlinear regression were used to conduct a detailed study. The time period of the study is July - December 2020.

Based on these initial data, we construct models of paired nonlinear regression and select the most statistically adequate ones for forecasting using the following algorithm (graph 1).

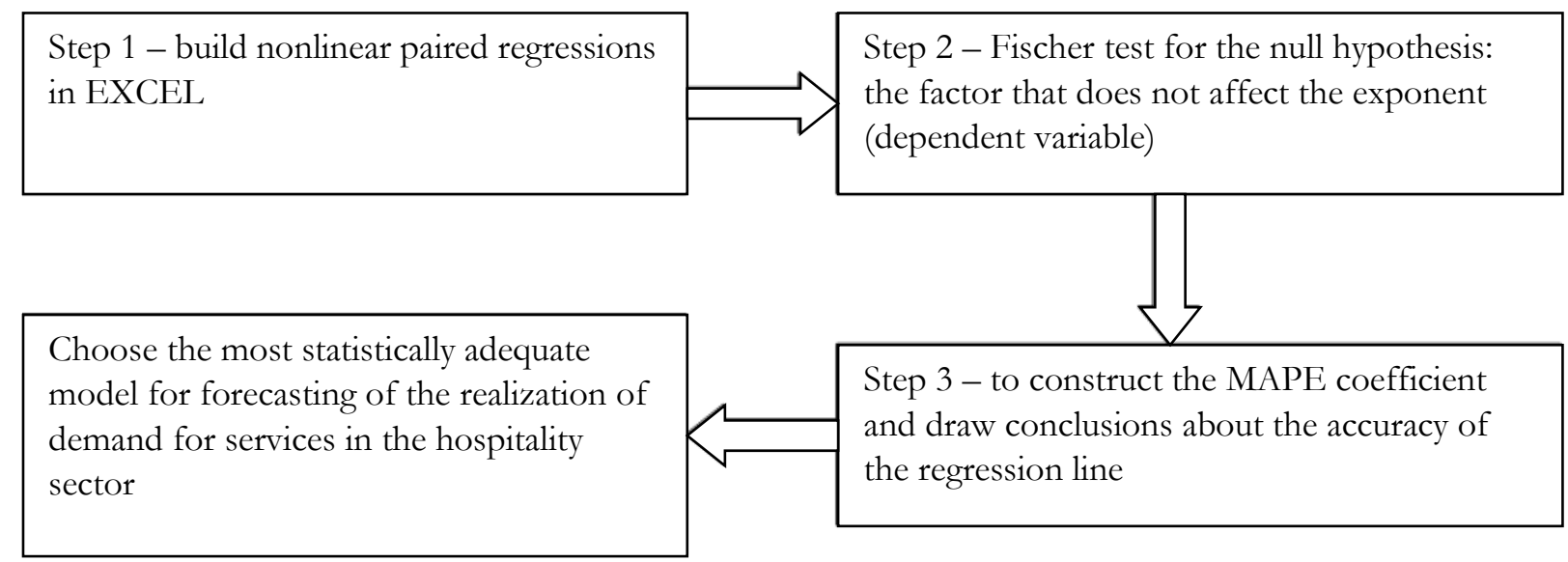

Graph 1. Algorithm of construction of regression models

Source: compiled by the author (Lopatin \& Chernenko, 2011)

Using the built-in MS Excel tools, a power model was constructed, the trend curve equation was derived, and the coefficient of determination R2 was determined. The construction of an equilateral regression 
hyperbola $y=a+b \frac{1}{x}$ was performed by replacement of the equilateral hyperbola model with a linear model by introduction of a new variable $U=\frac{1}{x}$.

To determine the coupling density between variables, the Fischer test was used to test the null hypothesis: "The Factor (independent variable) does not affect the indicator (dependent variable)".

Fischer's F-statistics were calculated using the Formula (1):

$$
F_{\text {comp }}=\frac{R^{2}}{1-R^{2}}(n-2)
$$

The MAPE coefficient characterizes the accuracy of sample approximation by the constructed regression equation.

The MAPE coefficient was calculated using the Formula (2):

$$
\text { MAPE }=\frac{1}{n} \sum\left(\frac{Y-Y \prime}{Y}\right) \cdot 100 \% \text {. }
$$

The MAPE coefficient (absolute percentage error test) characterizes the accuracy of the forecast. It is considered that a MAPE value of less than 10\% indicates high forecast accuracy; value from $10 \%$ to $20 \%$ good forecast accuracy; value from $20 \%$ to $50 \%$ - satisfactory accuracy; value of more than $50 \%$ unsatisfactory accuracy. In our case, we have a small sample size of $n=6$, since we analyzed data for six months of recovery of tourist flows during the period of easing of quarantine measures in countries around the world.

\section{EMPIRICAL RESULTS AND DISCUSSION}

The hospitality sector as a component of the tourism industry is certainly a business sector that was most affected by the COVID-19 pandemic. In most European countries and in Ukraine, the government issued direct orders to close hotels during the spring lockdown. It should be noted that there were no such directives in Germany, but according to the report of the European hotel Performance Update (CoStar, 2020), the occupancy of hotels and other accommodation facilities fell to a minimum of $4-5 \%$, because business trips and events were cancelled naturally, and air traffic was closed.

Impact of COVID-19 on the hospitality sector.

After the opening of European borders within the European Union and some EU countries and outside it (in particular, Bulgaria, Croatia, Albania, Montenegro) for tourists from third-party countries, the situation began to improve, but very slowly. In general, the hotel industry in Europe (current occupancy is about $40 \%$ ) is recovering more slowly than in the United States or China (occupancy is under 50\%) (Hospitalitynet, 2020).

In the United States, the occupancy rate of luxury hotels at the beginning of May 2020 was $\sim 15 \%$, of the economy class hotels $-\sim 40 \%$. Stock prices in the hotel business have fallen by $60 \%$ since January 1 , thousands of hotels have closed, which gives reason to expect full recovery of the market no earlier than in 2023.

The average September hotel occupancy in Europe was about 21\%, which is a positive trend compared to April and May, when the occupancy rate did not exceed 4-9\%. A positive trend is observed, but such indicators are not enough to fully ensure the operation of hotels. At the same time, only $10 \%$ of customers completely cancel their room reservations. The rest postponed their reservation - either for 2021 or for the fourth quarter of 2020. Thus, this indicates the realization of pent-up demand, and the highest priority task for hotel is to survive until the specified period.

The best situation is observed in resort hotels. On average, in large European cities, hotel occupancy is $20-30 \%$, and in the regions - $40-60 \%$. The reason for this was the growth of domestic tourism and tourism 
within the EU countries - tourists are more interested in resorts and regional attractions than capitals, where business life is usually concentrated (McKinsey \& Company, 2020).

The Asian hospitality sector is no less affected. For example, tourism in Thailand was almost completely suspended, which was caused by a sharp drop in the number of arrivals of foreign tourists after the outbreak of the pandemic. During the spring lockdown period, this drop was $76.4 \%$. Another consequence of the recession was the loss of jobs for almost one million employees in the hospitality industry (NTO Ukraine, 2020)

At the same time, a positive component for entrepreneurship in the hospitality industry is the fact that investment in the sector has been frozen, the completion dates of hotels under construction have shifted by one to two years, and, accordingly, reduced competition will help currently functioning hotels to recover faster.

Impact of COVID-19 on the tourism industry.

In Asia and the Pacific, which were the first regions affected by the pandemic, and the regions with the highest level of travel restrictions that exist even today, in January-October 2020, the number of tourist arrivals decreased by $82 \%$.

In the Middle East, tourist arrivals fell by $73 \%$, while in Africa, during the same period, the level of tourist arrivals decreased by 69\% (UNWTO, 2020).

Europe recorded a $76 \%$ reduction in tourist flows, although in some countries quarantine restrictions were eased during the summer tourism season.

The number of international arrivals to America decreased by 68\%. Arrivals in the Americas have been gradually improving since June, and there is now a positive trend, particularly among Caribbean island countries.

In the sub-regions of Western Europe, Central and Eastern Europe, Caribbean, North America, South America and sub-Saharan Africa, tourist arrivals decreased by $70 \%$ in the first ten months of 2020 . With a few exceptions, such as Andorra (-30\%), the US Virgin Islands (-38\%) and Austria (-46\%), most tourist destinations recorded a 50-90\% decrease in international arrivals between January and October 2020 (UNWTO, 2020).

Since June, many global destinations have eased travel restrictions, moving from a policy of completely closed borders to more targeted restrictions. The share of closed destinations decreased from $82 \%$ at the end of April 2020 to 18\% at the beginning of November. The actual number dropped from 156 countries in April to 59 in early November. Despite this, most countries adhere to certain entry and exit restrictions, in particular, such as mandatory quarantines or travel bans for Third-party countries tourist markets. In total, 59 destination countries supported "partial" border closures at the beginning of November, which is equivalent to $52 \%$ of arrivals in the world, while 95 countries had "other measures" (27\%) (UNWTO, 2020), including, in particular, PCR testing as a condition for making a trip or free entry to the country of arrival, but with the condition of staying in compliance with standard security requirements.

Regions in Europe saw the largest reduction in "total" border closures - from 92\% in late April to 3\% in early November, reflecting the opening of destinations across the European Union in late May and June for at least EU citizens.

In Asia and the Pacific, the share of "closed" countries also fell, albeit to a lesser extent (from $89 \%$ in April to 53\% in November), as several significant tourist destinations, such as China and Thailand, remained closed.

The "total closure" of countries in the Americas declined from $40 \%$ to $14 \%$ in the same period, reflecting the opening of borders at several destinations, mainly in the Caribbean. However, a number of countries are still closed for international travel. 
African destinations with "full closures" peaked at 91\% in May and fell to 11\% by November. In the Middle East, they reached $80 \%$ and then fell to $9 \%$.

As of November 1, the Asia-Pacific region was the only region where $53 \%$ of destinations remained closed. In the American, African and Middle Eastern regions, the share ranged from $9 \%$ to 14\%, while only $3 \%$ of European destinations remained completely closed (UNWTO, 2020).

Key trends in the hospitality sector, considering the realization of pent-up demand.

The spread of the COVID-19 pandemic has demonstrated to players in the travel services market and the hospitality industry that a hotel product is no longer just a room rate. A hotel service should inspire confidence and guarantee the safety of every consumer. It is important to review previous processes, consumer demand, and identify new customer categories and new services. In fact, today the hospitality industry needs to create a new portrait of the guest, assess their needs and understand what services they need.

Dynamic customer engagement and personalization of the service will require new systems that can provide a full cycle of interaction with the client. In this vein, the importance of CRM and loyalty systems will increase, because today it is especially important for hotels to build trust and develop communication with guests. The requirements for these technologies will grow: first, when new customer data appears (for example, Travel ID numbers or health passports, which are currently being actively discussed), and secondly, due to the need for the market to have orderly information about sanitary protocols in hotels.

So, two key trends in the hospitality sector in the current conditions of functioning of the tourism industry are:

1. Digitalization (automation of service processes using AI technologies; integrated guest applications; contactless services and SIP-DECT technologies, etc.);

2. Compliance with sanitary standards (regular cleaning and disinfection of rooms; thorough sanitary treatment of surfaces; washing of linen and towels only at high temperatures; non-contact frames for measuring the temperature of hotel guests; disinfection of luggage; new service formats in hotel restaurants and bars, etc.).

Mainly powerful hotels, hotel chains and partially small family hotels will be able to afford to meet the requirements in accordance with these trends, which, in turn, can negatively affect the sector of private accommodation in apartments, where, in turn, it is quite difficult to introduce innovations dictated by the requirements of the time, and track the implementation of safe recreation standards.

\section{Realization of pent-up demand in the hospitality sector}

The activity of consumers and the formation of demand for hotel services after the resumption of air traffic in the world is evidenced by the dynamics of consumer requests for popular online booking services Airbnb and Booking.com, shown in Graph. 2.

The selected data period for analysis is October 2019 - January 2021, except April-June 2020. This exclusion is due to the consequences of fight against coronavirus outbreak with a corresponding restriction on tourism in general and, in particular, a ban on the activities of accommodation establishments worldwide. Thus, in fact, from the end of March to the beginning of April 2020, the traffic to visit online booking sites and, in turn, the load of hospitality enterprises decreased to zero and remained in this value almost until early July, when flights were resumed and, accordingly, international travel could the maximum extent possible at that time. Starting from July 2020, we can observe a gradual increase in traffic with its corresponding fluctuations until January 2021. 


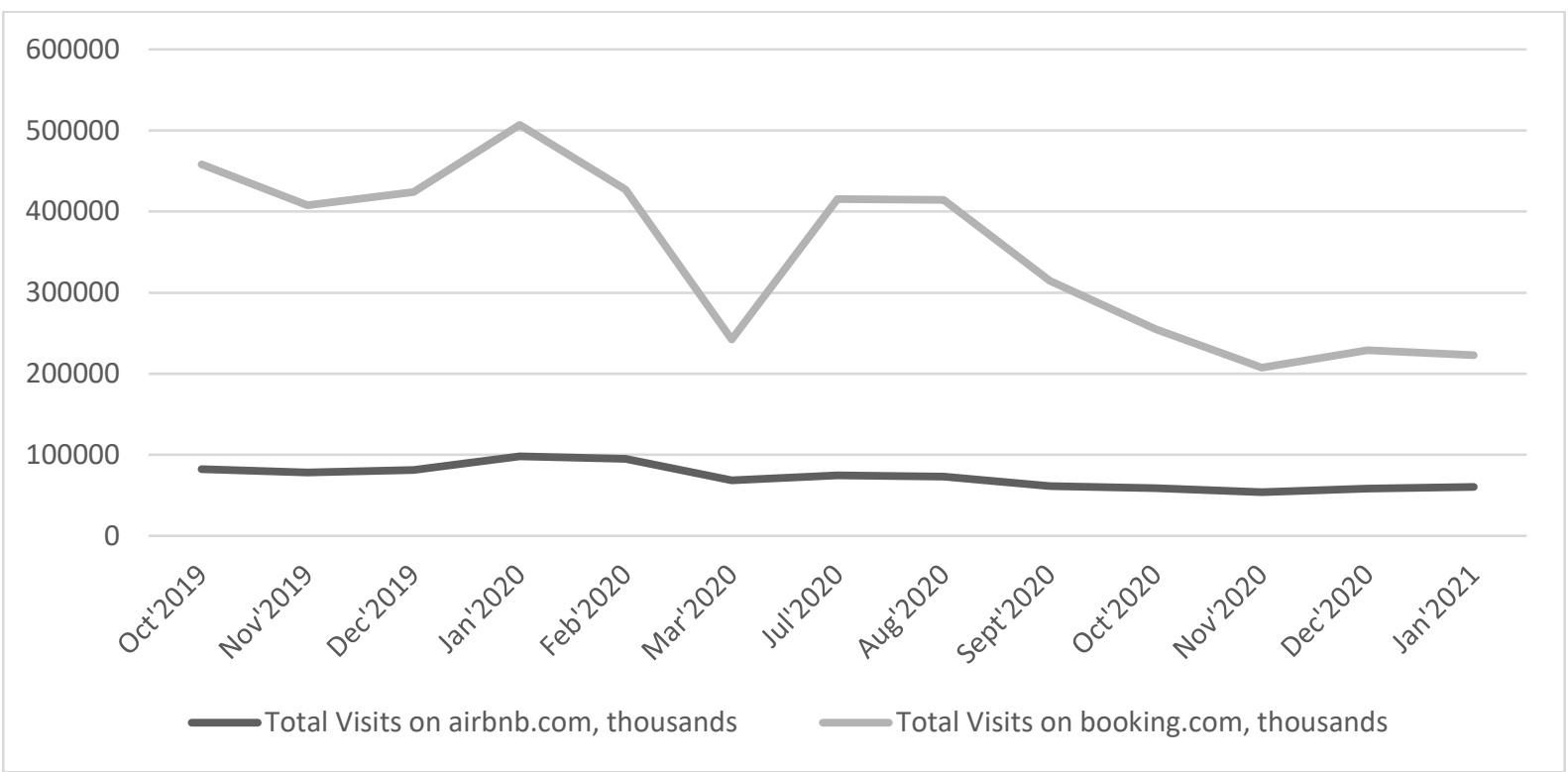

Graph 2. Dynamics of consumer requests on popular online booking service platforms Airbnb and Booking.com for the period October 2019 - January 2021 (excluded period April 2020-June 2020)

Source: data based on Similarweb.com

The data in this figure indicate a trend of low consumer requests on the Airbnb online booking platform from July 2020, which is primarily due to the inability of the private accommodation sector to provide the necessary sanitary requirements to counteract COVID-19 and certain restrictions related to the possibility of booking in these accommodation facilities. In the pre-quarantine period, the dynamics of requests was more positive. The period October-December 2019 indicates moderate growth, due to the traditional increase in demand in the pre-Christmas period. The peak of consumer demand falls on JanuaryFebruary 2020, which is because the main consumers of Airbnb services are young people who are on vacation during this period.

In turn, on the platform of online booking services Booking.com which specializes in the provision of booking services mainly in certified hotels, there is a traditional fluctuation of consumer demand within the norm in the period October 2019 - January 2020. Since February 2020, there has been a sharp drop in demand, the anti-record of which is observed in March 2020, due to the COVID-19 outbreak. Some growth since April 2020 is due primarily to visits to the platform to cancel or reschedule orders for a later period. After the resumption of international tourism there is a consistently high dynamics of requests in the traditional months of the high summer season with a gradual decrease in them during the autumn, which is associated with both a standard decrease in demand for travel during this period, and with the autumn tightening of restrictive measures in several countries around the world. At the same time, since the end of November and throughout December, we have seen a positive trend in requests, related to the easing of some quarantine restrictions during the Christmas period and the desire of consumers to relax during the Christmas and New Year holidays. The data in the figure shows consumer confidence in certified hotels and Booking.com as an intermediary in the implementation of measures for safe recreation in the conditions of COVID-19.

The hypothesis of the study of the realization of pent-up demand is based on the fact that there is a non-linear relationship between incoming traffic, that is, consumers' visits to online booking sites and the volume of tourist arrivals, which indicate the volume of realized demand for accommodation facilities. To 
test this hypothesis we will use the generalized UNWTO data on tourist arrivals and platform data similarweb.com, which characterize the statistics of visits to the online booking platform Booking.com for the period July - December 2020 (Table 1).

Table 1

Summary data of the Booking.com incoming traffic volume and the volume of tourist arrivals

\begin{tabular}{|l|c|c|}
\hline & $\begin{array}{c}\text { Total Visits on booking.com, } \\
\text { thousands (Similarweb.com) }\end{array}$ & $\begin{array}{c}\text { International Tourist Arrivals, million } \\
\text { (UNWTO) }\end{array}$ \\
\hline & $\mathrm{X}$ & Y \\
\hline Oct'2019 & 458000 & 119.81 \\
\hline Nov'2019 & 408000 & 100.12 \\
\hline Dec'2019 & 424000 & 109.52 \\
\hline Jan'2020 & 507000 & 99.53 \\
\hline Feb'2020 & 427000 & 85.54 \\
\hline Mar'2020 & 242000 & 44.55 \\
\hline Jul'2020 & 415500 & 29.18 \\
\hline Aug'2020 & 414500 & 33.56 \\
\hline Sept'2020 & 314500 & 29.18 \\
\hline Oct'2020 & 255000 & 39.39 \\
\hline Nov'2020 & 207500 & 40.85 \\
\hline Dec'2020 & 229000 & 42.31 \\
\hline Jan'2021 & 223000 & 38.89 \\
\hline
\end{tabular}

Source: data based on Similarweb.com and UNWTO

Based on these initial data, nonlinear regression models were constructed and the most statistically adequate ones for forecasting were selected - this is the power model (graph 3) and a model based on an equilateral Hyperbola (graph 4) - according to the chosen research methodology.

For each model, the following indicators were calculated: the Fischer criterion to characterize the tightness of the connection and the average error of the approximation - MAPE coefficient. Let's estimate the statistical significance of the regression parameters in Table 2:

Table 2

Summary table of parameters of nonlinear regression models

\begin{tabular}{|l|c|c|}
\hline \multicolumn{1}{|c|}{ Parameter } & $\begin{array}{c}\text { Power model } \\
Y=0.0002 x^{0.3453}\end{array}$ & $\begin{array}{c}\text { Equilateral Hyperbola model } \\
Y=-20610 x+127.54\end{array}$ \\
\hline$\alpha_{0}=$ & 0.0002 & -20610 \\
\hline$\alpha_{1}=$ & 0.9834 & 127.54 \\
\hline$R^{2}=$ & 0.3453 & 0.3838 \\
\hline$M A P E=$ & 38.2539 & 24.2227 \\
\hline$F_{\text {comp }}$ & 5.802 & 6.8513 \\
\hline$F_{\text {crit. }}$ & 3.23 & 3.23 \\
\hline
\end{tabular}

Source: own data 


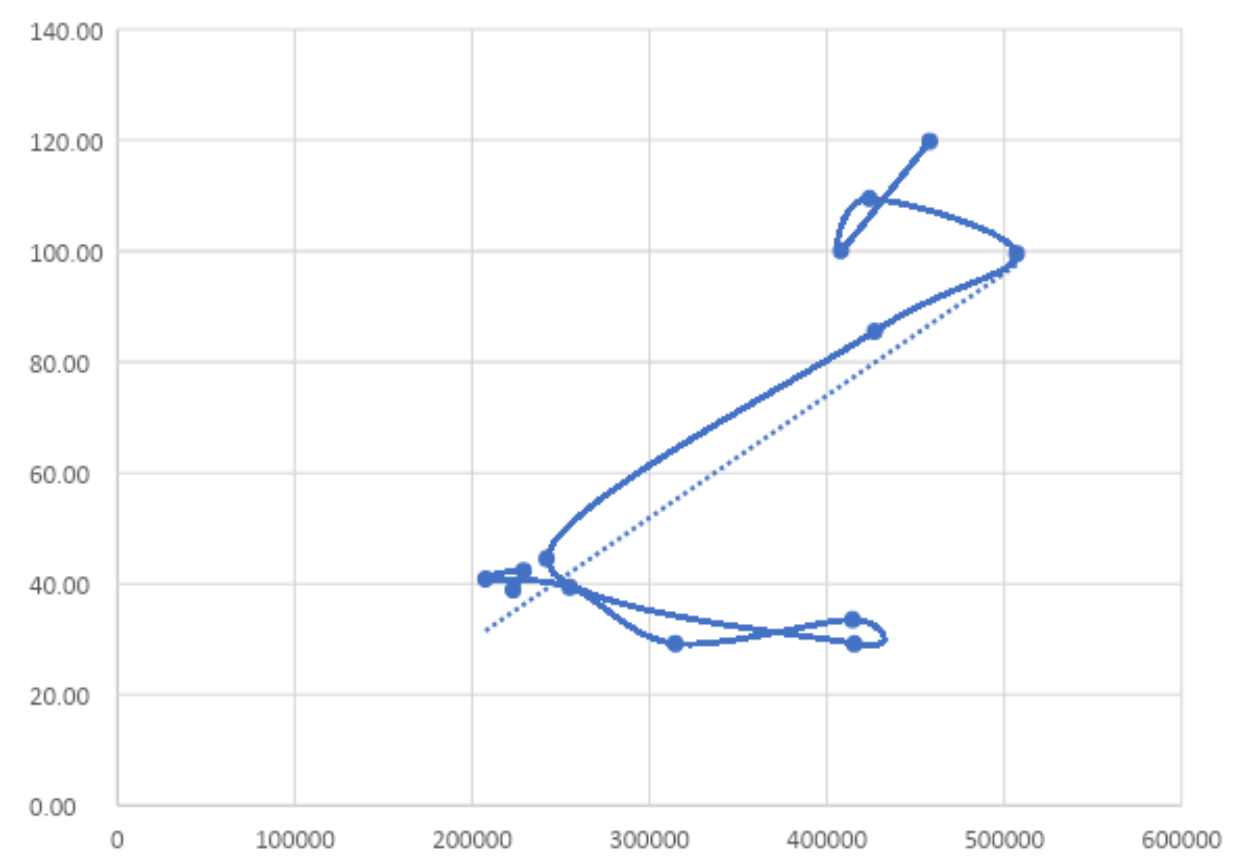

Graph 3. Power dependency model of International Tourist Arrivals from Total Visits on booking.com

Source: own data

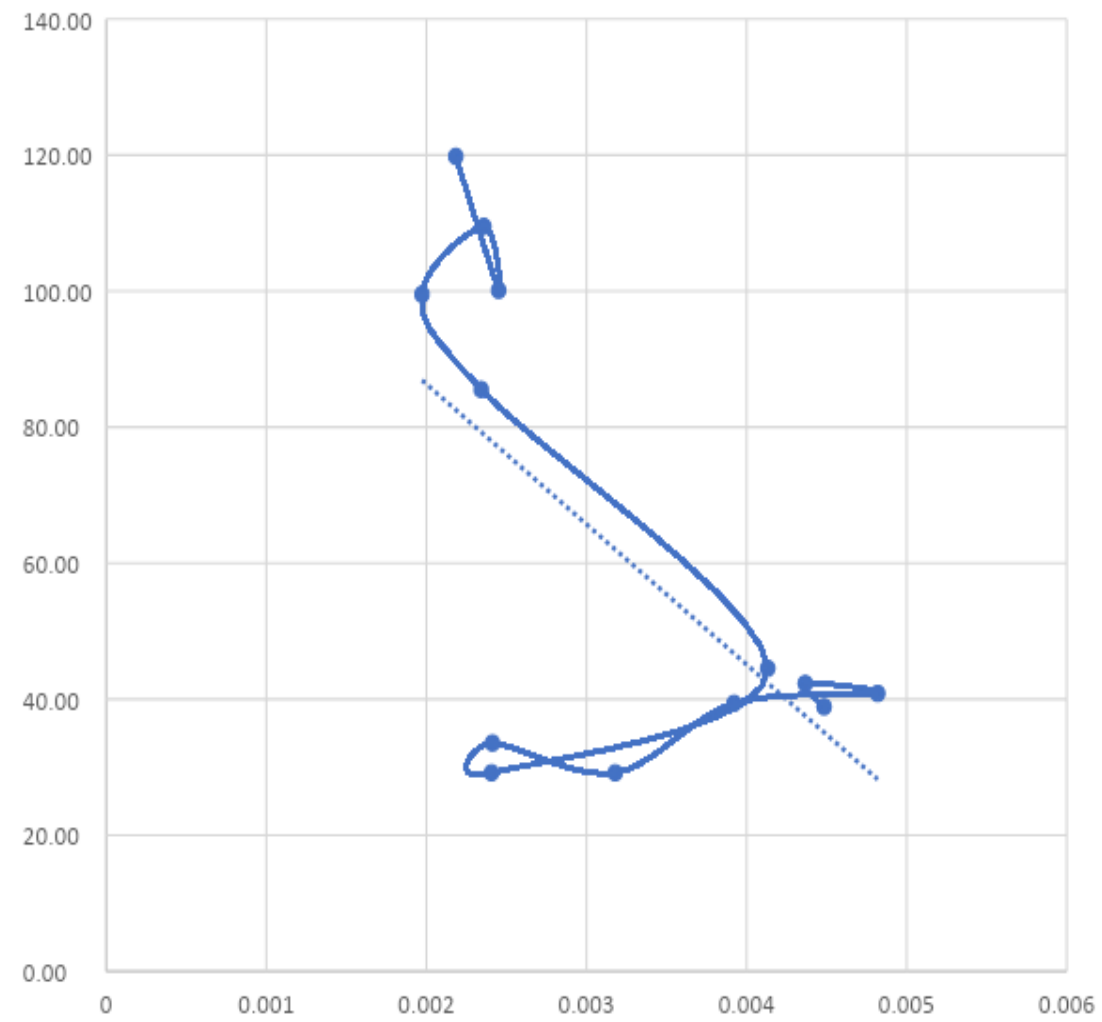

Graph 4. Hyperbolic dependency model of International Tourist Arrivals from total Visits on booking.com

Source: own data 
From Table 2 we can conclude that the result of modelling using nonlinear regression models is satisfactory, because according to Fischer's criterion, we can reject the null hypothesis (Fcomp $>$ Fcrit), and according to the value of the MAPE coefficient, which is between $20 \%$ and $50 \%$, in this model, we can get a satisfactory accuracy of prediction of the realization of demand for hospitality services.

Analysis of the residue gives an indication of how well the regression model selected.

According to the general theory, residues should behave as independent (or almost independent) equally distributed random variables. To obtain confidence intervals forecasting methods in classical regression analysis also assumed normal distribution of residuals.

Take the necessary calculations to verify the normality of distribution residues. We build a scattering diagram based on the results of that calculation (graph 5).

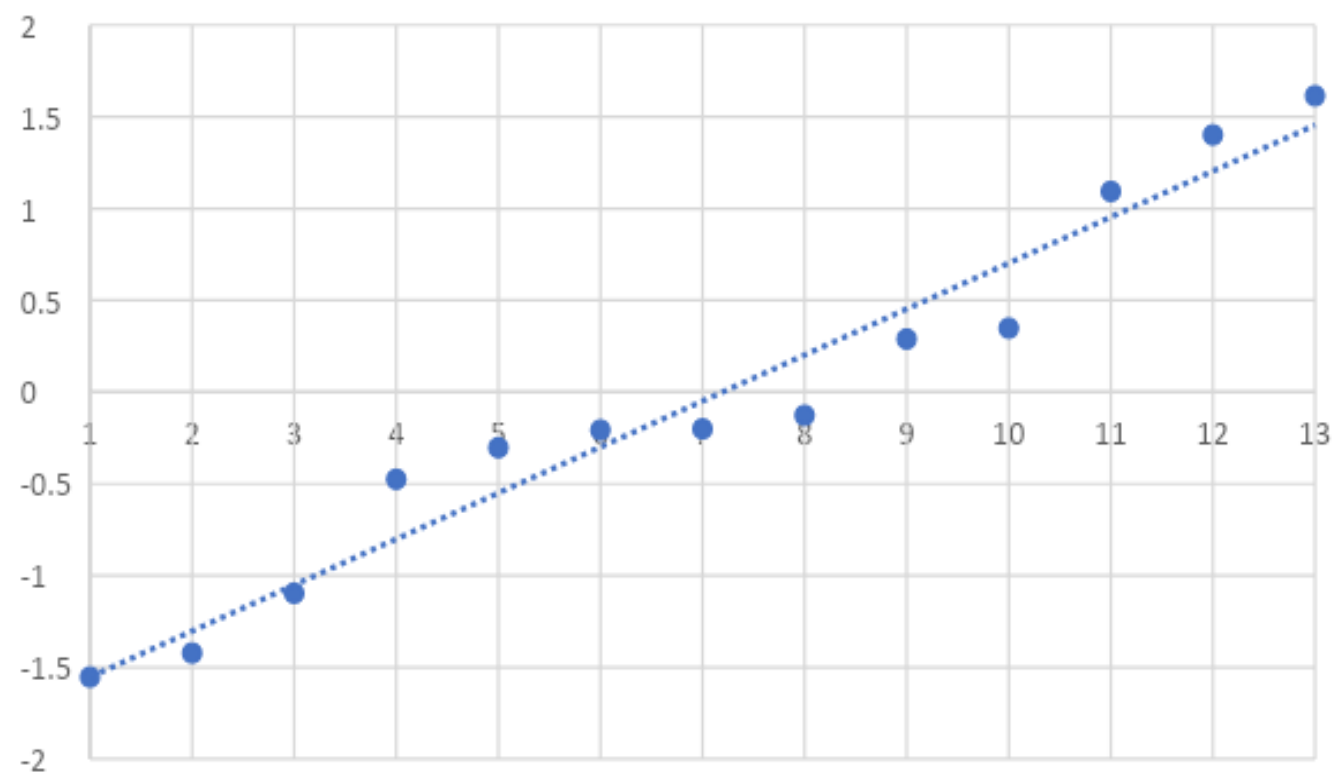

\section{Graph 5. Checking the normality of the distribution of residues}

Source: own data

Since all residues are located in the vicinity of the line, we can assume that the distribution of residues is approximately normal.

In this case, the parameters indicate that both models are statistically adequate (since all assumptions about the statistical properties of errors are fulfilled), respectively, the obtained regressions can be used to forecast the realization of demand in the hospitality sector.

The constructed models characterize trends in the realization of pent-up demand for services in the hospitality sector, which can be predicted based on data on incoming traffic of online booking platforms, which in turn characterizes the potential demand for hospitality services.

To test the constructed nonlinear regression models, we will forecast the realization of demand for both models with the same value of the variable $\mathrm{X}$ (incoming traffic to the online booking platform Booking.com). Let's assume that incoming traffic to the online booking platform Booking.com will increase by $20 \%$ from the level of December 2020 (Scenario A) or by $50 \%$ (Scenario B). 
Forecast of International Tourist Arrivals based on Total Visits on Booking.com

\begin{tabular}{|l|c|c|}
\hline \multicolumn{1}{|c|}{ Parameter } & \multicolumn{1}{|c|}{$\begin{array}{c}\text { Power model } \\
Y=0.0002 x^{0.3453}\end{array}$} & $\begin{array}{c}\text { Equilateral Hyperbola model } \\
Y=-20610 x+127.54\end{array}$ \\
\hline \multicolumn{2}{|c|}{ Scenario A (20\% increase in incoming traffic compared to December 2020) } \\
\hline $\begin{array}{l}\text { Total Visits on Booking.com, thousands } \\
(\mathrm{X} 1)=\end{array}$ & 274800 & 274800 \\
\hline $\begin{array}{l}\text { International Tourist Arrivals, million (Y1) } \\
=\end{array}$ & 44.64 & 52,54 \\
\hline \multicolumn{2}{|c|}{ Scenario B (50\% increase in incoming traffic compared to December 2020) } \\
\hline $\begin{array}{l}\text { Total Visits on Booking.com, thousands } \\
\text { X1) }=\end{array}$ & 343500 & 343500 \\
\hline $\begin{array}{l}\text { International Tourist Arrivals, million (Y1) } \\
=\end{array}$ & 55.60 & 67,54 \\
\hline
\end{tabular}

Source: own data

Thus, we can see that forecasting, using both models gives approximately the same result of the value of realized demand. In fact, we have not considered random error, because the true value is in a certain range. It shows that an error value $\varepsilon$ should be added to the developed nonlinear mathematical models, and that an increase in incoming traffic to the site (i.e., potential demand) does not always lead to an increase in the volume of realized demand. This potential demand becomes realized when temporary accommodation is booked. In the context of digitalization of the economy and Public Relations, data of the usage of digital resources is a source of information about socio-economic processes and can become the basis for market or industry, or sectoral trends forecasting.

\section{CONCLUSION AND IMPLICATION}

Summing up the results of the study, we note that we can already observe the realization of pent-up demand in the hospitality industry, which indicates a rather optimistic scenario for the recovery of international tourism in the coming years. At the same time, we consider it appropriate to focus on the main trends in the travel industry, which will be present in the tourism sphere during 2021.

First, the trend of long-term recreation or, so-called, staycation, which is associated with the stay of tourists outside their permanent place of residence for 14 or more days or making several trips per year, will become popular.

Secondly, remote work from anywhere in the world or workation. In fact, we are waiting for the era of "digital nomad", which provides the opportunity to work from anywhere where there is wi-fi and discounts from hotels for long-term stays (today the leaders in workation are Bali, Bermuda, Barbados, Aruba and Croatia).

Third, contactless technology and the best service with health care. In the process of resuming of tourist travel, tourists prefer airlines, airports and hotels with higher standards of health safety. Many companies have quickly adapted to these demand features: Hilton Hotels now offers contactless hotel check-in; Marriott staff cleans with electrostatic sprayers; IHG has created a special cleanliness Council called "Commitment to cleanliness".

Fourth, travel agents and travel consultants - assistants in travel organization. The pandemic has only highlighted the crucial role of travel agents and travel consultants. Rapid-changing conditions of entry to certain countries, nuances of insurance and PCR testing, new conditions of stay in all world destinations all this is too difficult to learn for a person who is far from tourism and literally does not "live in it". Therefore, in 2021, travel agencies will become the most important sources of knowledge. 
Fifth, the trend of booking "at the last minute" will continue, and "early booking" will be forced to be on pause, which is due to the fear of tourists to book flights and hotel rooms in advance due to the variability of entry conditions and the openness of destination countries.

Sixth, the growing popularity of car travel, quite often - within the country.

Seventh, the revival of business tourism is associated with the restoration of various sectors of the economy and business environment.

Eighth, the issue of vaccination and the introduction of health passports remains open, because now opinions about the need to introduce this tool are divided both among specialists in the hospitality industry and the tourism services market as a whole, as well as among representatives of world political structures.

In general, 2021 has all the prospects and opportunities to become a record year for the tourism industry, taking into account the level of bookings, the resumption of international arrivals and the desire of tourists from all over the world to travel, which indicates the unconditional realization of the pent-up demand for travel among consumers.

\section{REFERENCES}

Bakar, N.A., \& Rosbi, S. (2020). Effect of Coronavirus disease (COVID-19) to tourism industry. International Journal of Advanced Engineering Research and Science, 7, 4. https://dx.doi.org/10.22161/ijaers.74.23

Burkle, Fm.Jr. (2006). Globalization and natural disasters: issues of public health, public capacity and political action, Journal of International Relations, 59 (2), 231-265.

Butorov, S.A. (2020). The COVID-19 pandemic and impact on the world tourist industry, Bulletin of MGUKI, 2 (94), 116-125.

ETOA Başkanı Tom Jenkins: Krize rağmen talep güçlü plans (2020, December 19). Retrieved from https://www.turizmguncel.com/haber/etoa-baskani-tom-jenkins-krize-ragmen-talep-guclu

Cajner, T., Crane, L.D., Decker, R.A., Hamins-Puertolas, A., \& Kurz, C. (2020, May 18). Tracking Labor Market Developments during the COVID-19 Pandemic: A Preliminary Assessment. Retrieved from https://www.federalreserve.gov/econres/feds/files/2020030pap.pdf

Centeno, R.S., \& Marquez, J.P. (2020, April 21). How much did the Tourism Industry Lost? Estimating Earning Loss of Tourism in the Philippines. Retrieved from https://arxiv.org/pdf/2004.09952.pdf

Günay, F., Bayraktaro glu, E., \& Özkul, K. (2020). Assessing the Short-term Impacts of COVID-19 Pandemic on Foreign Visitor's Demand for Turkey: A Scenario Analysis, Journal of Ekonomi, 2, 80-85.

Hospitality and COVID-19: How long until 'no vacancy' for US hotels? (2020, June 10). Retrieved from https://www.mckinsey.com/industries/travel-logistics-and-transport-infrastructure/ourinsights/hospitality-and-covid-19-how-long-until-no-vacancy-for-us-hotels

Kabelkaite-Vaitkene, Yu. A. (2020). Challenges and opportunities of the hospitality industry in conditions of distribution of coronavirus infection, Digital Science, 10, 35-45.

Kostynets, I., Kostynets, V., \& Baranov V. (2020). Pent-up demand effect at the tourist market. Economics and Sociology, 13(2), 279-288. doi: 10.14254/2071-789X.2020/13-2/18

Lopatin, O.K., Chernenko, O.B. (2011). Econometrics. National Academy of Management. http://dx.doi.org/10.2139/ssrn.3612676

Ozili, P.K., \& Arun, T. (2020, March 27). Spillover of COVID-19: Impact on the Global Economy. Retrieved from https://ssrn.com/abstract $=3562570$

Priyadarshini, I. (2020, June 1). A Survey on some of the Global Effects of the COVID-19 Pandemic. Retrieved from https://www.researchsquare.com/article/rs-20842/v1

STR: Europe Hotel Performance for June 2020 (2020, September 2). Retrieved from https://www.costar.com/article/566122635

STR: Europe hotel performance for November 2020 (2020, December 23). Retrieved from https://www.hospitalitynet.org/news/4102258.html

The COVID-19 pandemic and implications in the tourism sector in Ukraine (2020, December 24). Retrieved from http://www.ntoukraine.org/assets/files/EBRD-COVID19-Report-UKR.pdf 
Toynbee, A. J. (2019). Comprehension of history. Academic project.

Tourism back to 1990 levels as arrivals fall by more than 70\% (2020, December 17). Retrieved from https://www.unwto.org/news/tourism-back-to-1990-levels-as-arrivals-fall-by-more-than-70 